ПОРІВНЯЛЬНИЙ АНАЛІЗ ДУМКИ ВЧИТЕЛІВ ФІЗИЧНОЇ КУЛЬТУРИ

Й УЧИТЕЛІВ ПОЧАТКОВИХ КЛАСІВ ЩОДО ВПРОВАДЖЕННЯ

КЛЮЧОВИХ КОМПЕТЕНТНОСТЕЙ НОВОЇ УКРАЇНСЬКОЇ ШКОЛИ

У ФІЗИЧНЕ ВИХОВАННЯ

\title{
THE COMPARABLE ANALYSIS OF PHYSICAL EDUCATION TEACHERS AND PRIMARY EDUCATION TEACHERS' ATTITUDE TOWARDS IMPLEMENTATION OF NEW UKRAINIAN SCHOOL KEY COMPETENCES INTO PHYSICAL EDUCATION
}

УДК 796.011.3:373-053.5

DOI https://doi.org/10.32843/2663-

$6085 / 2020 / 22-4.14$

\section{Сороколіт Н.С.,}

канд. наук з фіз. виховання і спорту, доцент кафедри теорії та методики фрізичної культури

Львівського державного університету фрізичної культури імені Івана Боберського

\begin{abstract}
Стаття присвячена одній із актуальних проблем фрізичного виховання на сучасному етапі, а саме компетентнісному підходу у фрізичному вихованні школярів. Проаналізовано результати опитування вчителів фрізичної культури й учителів початкових класів щодо впровадження ключових компетентностей під час фрізкультурнооздоровчої роботи в школі. Мета дослідження - здійснити порівняльний аналіз ставлення вчителів фрізичної культури й учителів початкових класів до можливості впровадження ключових компетентностей освітньої рефрорми «Нова українська школа» у фрізичне виховання школярів. Методи дослідження - аналіз та узагальнення літературних джерел, офріційних документів та опитування педагогів шляхом анкетування. На запитання анкети відповідали 204 педагоги, з них - 100 вчителів фрізичної культури та 104 вчителі початкових класів Львівської області різного педагогічного стажу й категорій. Виявлено, що такі ключові компетентності, як вільне володіння державною мовою (98,0\% учителів фрізичної культури та 92,3\% вчителів початкових класів), культурна компетентність (70,0\% учителів фрізичної культури та 69,2\% вчителів початкових класів) $і$ навчання впродовж життя (62,0\% вчителів фоізичної культури та 65,3\% вчителів початкових класів), найлегше реалізувати у фрізичному вихованні для обох категорій респондентів. Виявлено труднощі з реалізацією такої ключової компетентності, як «підприємливість та фрінансова грамотність». На думку $56,0 \%$ учителів фрізичної культури та $57,7 \%$ вчителів початкових класів, важко реалізувати чю ключову компетентність. Отже, незважаючи на те що сьогодні освітня ресрорма «Нова українська школа» впроваджена лише в початковій школі, думка вчителів фрізичної культури й учителів початкових класів щодо можливостей упровадження ключових компетентностей у різичне виховання школярів є подібною.

Ключові слова: ключові компетентності, Нова українська школа, фрізичне виховання,
\end{abstract}

учителі фрізичної культури, учителі початкових класів.

The article is dedicated to one of the most actual problems of physical education nowadays. In particular, to competence approach in pupils' physical education. There were analyzed the results of physical education and primary education teachers' surveys according key competences implementation during the physical-wellness work in school. The goal of the research is to provide comparative analysis of physical education and primary education teachers' attitude towards the opportunity to implement key competences of educational reform "New Ukrainian School" into pupils" physical education. The methods of research are analysis and literature sources, official documents generalization and pedagogues' surveys by questionnaire. The questions were answered by 204 pedagogues, among them are 100 physical education teachers and 104 primary education teachers with different work experience and category. All teachers are from Lviv region. In result we have found out that both categories of teachers it is the most easy way to implement such key competences as to be fluent in native language $(98.0 \%$ of physical education teachers and $92.3 \%$ of primary education teachers), culture competence $(70.0 \%$ physical education teachers and $69.2 \%$ of primary education teachers) and studying during the whole life $(62.0 \%$ of physical education teachers and $65.3 \%$ of primary education teachers). We have noticed some difficulties with realization of such key competences as "Entrepreneurship and financial literacy. $56.0 \%$ of physical education teachers and $57.7 \%$ of primary education teachers think it is difficult to realize this key competence. In conclusion: even though educational reform "New Ukrainian School" is implemented only in primary school nowadays, physical education teachers' opinion and primary education teachers'opinion about opportunities to implement key competences in pupils' education is common. Key words: key competences, New Ukrainian School, physical education, physical education teachers, primary education teachers.
Постановка проблеми в загальному вигляді. Упродовж останніх років наша країна впевнено рухається шляхом глибоких і структурних реформ у всіх галузях суспільства. Вітчизняні науковці стверджують, що українська освіта не відповідає ані сучасним запитам з боку особистості й суспільства, ані потребам економіки, ані світовим тенденціям [3, с. 39; 6; 9]. Саме тому розпочато системну трансфрормацію освітньої сорери, головна мета якої - нова висока якість освіти на всіх рівнях: від початкової школи - до закладів вищої освіти [8]. Масштабне реформування освіти в Україні стало можливим завдяки прийняттю Закону України «Про освіту», який задекларував усебічний розвиток людини як особистості й найвищої цінності суспільства, їі талантів, інтелектуальних, творчих і фрізичних здібностей, формування цінностей і необхідних для успішної самореалізації 
компетентностей, виховання відповідальних громадян, які здатні до свідомого суспільного вибору та спрямування своєї діяльності на користь іншим людям і суспільству, збагачення на цій основі інтелектуального, економічного, творчого, культурного потенціалу українського народу, підвищення освітнього рівня громадян задля забезпечення сталого розвитку України та її європейського вибору [2].

Нові виклики часу, динамічний розвиток інорормаційних технологій, евроінтеграційний вектор в освітній політиці нашої держави та прагнення України ввійти до європейського освітнього простору актуалізують дії освітянської спільноти щодо рефрормування освіти, її стратегічних напрямів і концептуальних положень. Новітнє суспільство висуває до освіти нові вимоги, однією з яких є фрормування особистостей, що спроможні ухвалювати неординарні рішення й ефективно налагоджувати взаємини у швидкоплинній реальності. Активність, самостійність, творчість, здатність адаптуватися до стрімких змін - ці риси особистості дуже важливі на сучасному етапі історичного розвитку, а їх формування потребує реалізації нових підходів до процесу навчання [4, с. 224]. Сучасні випускники потребують не тільки ґрунтовних знань із предметів, а й високого рівня розвитку різних типів компетентностей [5, с. 13].

Саме компетентністний підхід до навчання закладено в основі концепції Нової української школи, який доповнюють принципи дитиноцентризму та педагогіки партнерства, новий зміст освіти, а також сучасне освітнє середовище - безпечне, доступне та дружнє до дитини [2].

Аналіз останніх досліджень і публікацій. Обговорення й дослідження компетентісного підходу з погляду міжнародної спільноти та перспектив його впровадження в досвід української освіти висвітлюються в публікаціях Л. Гриневич [5, с. 10], О. Ляшенка [3, с. 40], О. Пометун [7, с. 18], Н. Москаленко [4, с. 226] та ін.; питання про впровадження окремих ключових компетентностей у навчальновиховний процес школярів розглядали О. Савченко [10, с. 17], Н. Бібік [1, с. 47], Л. Паращенко [6] та інші.

Окрім цього, сутність компетентнісного підходу й проблеми орормування ключових компетентностей аналізуються в роботах таких зарубіжних дослідників, як R. Barnett [12], W. Westera [14], J. Raven, Stephenson [13] та ін.

Виділення не вирішених раніше частин загальної проблеми. Незважаючи на численні наукові дослідження щодо застосування компетентнісного підходу в навчанні школярів, ми не знайшли наукових досліджень, які окреслюють реалізацію ключових компетентностей нової української школи у фрізичному вихованні. У зв'язку 3 цим постає потреба в розкритті можливостей реалізації ключових компетентностей у фрізичному вихованні школярів.
Мета статті - здійснити порівняльний аналіз ставлення вчителів фрізичної культури й учителів початковихкласівдоможливостівпровадженняключових компетентностей освітньої реформи «Нова українська школа» у фрізичне виховання школярів.

Виклад основного матеріалу. Для реалізації поставленої мети ми провели опитування вчителів фрізичної культури й учителів початкових класів закладів загальної середньої освіти Львівської області 3 різним педагогічним стажем і рівнем професійності. На запитання анкети відповідали 204 педагоги, 3 них - 100 вчителів фрізичної культури, серед яких - 44,0\% - спеціалісти вищої, 24,0\% - першої, 14,0\% - другої категорій, 18,0\% молоді учителі (спеціалісти); 104 вчителі початкових класів Львівської області, з них - 55,8\% вищої, 26,9\% - першої, 3,9\% - другої категорій, 13,5\% - молоді спеціалісти. Усі респонденти дали згоду на участь у дослідженні.

Проведене нами опитування педагогів дає змогу стверджувати, що думка вчителів фрізичної культури й учителів початкових класів щодо компетентнісного підходу у фрізичному вихованні школярів у деяких випадках $€$ подібною. Такі ключові компетентності, як вільне володіння державною мовою, культурна компетентність, навчання упродовж життя, екологічна компетентність, на думку педагогів, можуть бути досить легко реалізовані у фрізичному вихованні школярів. Так, 98,0\% учителів фрізичної культури та 92,3\% вчителів початкових класів не вважають складним завданням реалізацію ключової компетентності «вільне володіння державною мовою» у фрізичному вихованні школярів. Основною формою реалізації цієї ключової компетентності педагоги вважають спілкування під час фрізкультурно-оздоровчої діяльності зі школярами. Педагоги пропонували під час уроку фрізичної культури застосовувати лічилки, віршики та спортивну термінологію.

Ми виявили однакову думку серед двох категорій респондентів щодо можливостей реалізації культурної компетентності під час уроків фрізичної культури. Про це стверджують 70,0\% учителів фрізичної культури та 69,2\% вчителів початкових класів. Для 28,0\% учителів фрізичної культури та 19,2\% вчителів початкових класів реалізація цієї ключової компетентності у фрізичному вихованні школярів викликає труднощі. Ми це пов'язуємо 3 тим, що для вчителів фрізичної культури культурна компетентність асоціюється із запровадженням під час уроків фрізичної культури елементів національної культури, таких як народні рухливі ігри, обряди, гаївки, а також культури рухів. Припускаємо, що для вчителів початкових класів культурна компетентність пов'язана насамперед із мистецтвом, архітектурою, народними промислами та елементами народного танцю, що, у свою чергу, вимагає музичного супроводу й додаткового обладнання. 
Практично не відрізняється думка вчителів фрізичної культури й учителів початкових класів щодо можливості реалізації у фрізичному вихованні школярів такої ключової компетентності, як навчання упродовж життя. Легким завданням це виявилося для 62,0\% вчителів фрізичної культури та 65,3\% вчителів початкових класів. Варто зазначити, що ми встановили достовірну різницю

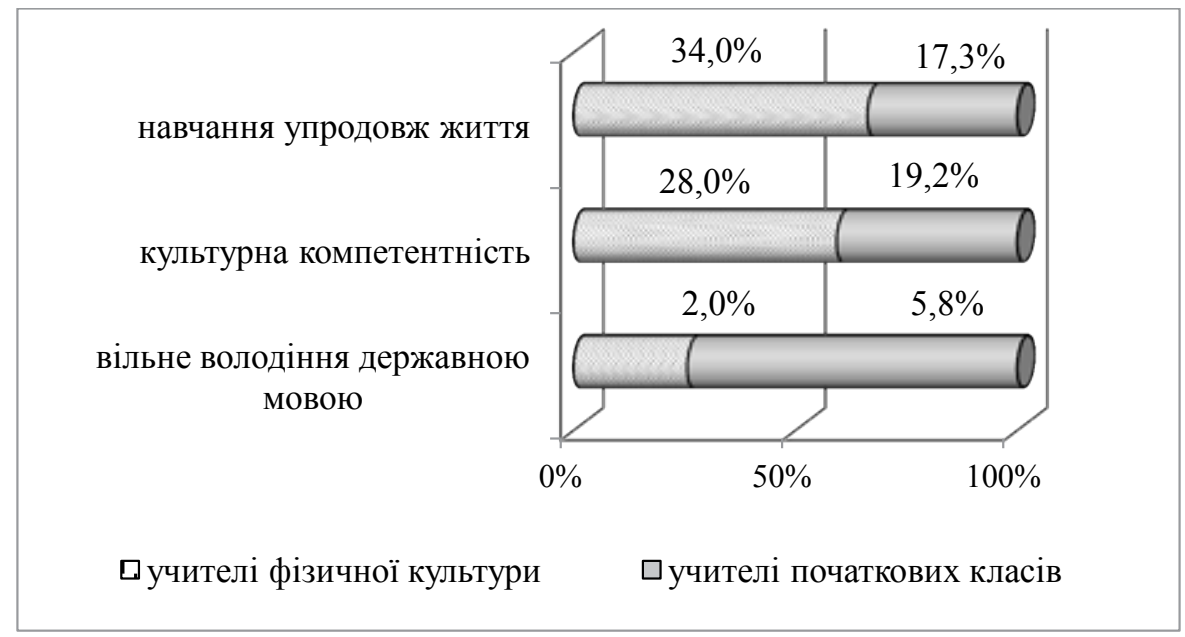

a)

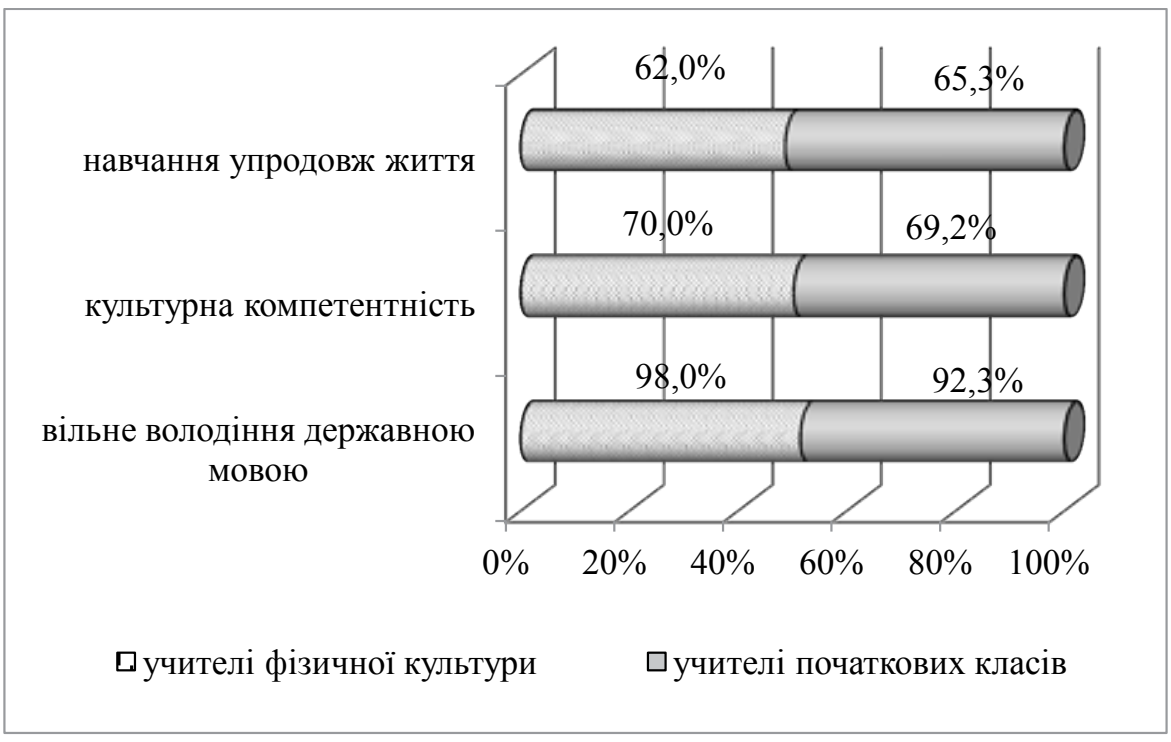

б)

Рис. 1. Думка педагогів щодо можливостей реалізації компетентностей (а - легкість реалізації у фрізичному вихованні; б - складність реалізації у фрізичному вихованні)

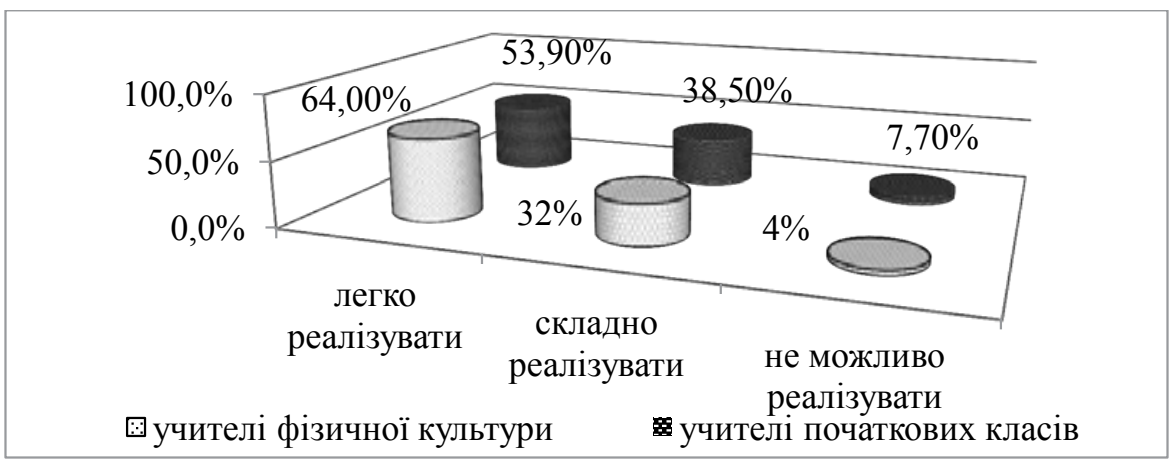

Рис. 2. Думка педагогів щодо можливого впровадження математичної компетентності у фрізичному вихованні 
Думка респондентів щодо реалізації двох компетентностей

\begin{tabular}{|c|c|c|c|c|c|c|}
\hline \multirow{4}{*}{ Ключова компетентність } & \multicolumn{6}{|c|}{ Відповіді респондентів (\%) } \\
\hline & \multicolumn{3}{|c|}{ Учителі фрізичної культури (n=100) } & \multirow{2}{*}{\multicolumn{3}{|c|}{$\begin{array}{l}\text { Учителі початкових класів (n=104) } \\
\text { алізації }\end{array}$}} \\
\hline & \multicolumn{5}{|c|}{ Ступінь реалізації } & \\
\hline & Легко & Складно & Неможливо & Легко & Складно & Неможливо \\
\hline $\begin{array}{l}\text { Компетентності в галузі природни- } \\
\text { чих наук, техніці й технологіях }\end{array}$ & $46 \%$ & $46,0 \%$ & $8 \%$ & $42,3 \%$ & $38,5 \%$ & $19,2 \%$ \\
\hline Екологічна компетентність & $62 \%$ & $32 \%$ & $6 \%$ & $61,5 \%$ & $23,1 \%$ & $15,4 \%$ \\
\hline
\end{tabular}

у відповідях респондентів щодо складності й неможливості реалізації цієї ключової компетентності засобами фрізичного виховання. Про складність такої реалізації висловилися 34,0\% вчителів фрізичної культури та 17,3\% вчителів початкових класів. Неможливим процесом виявилося це для 4,0\% учителів фрізичної культури та 17,3\% вчителів початкових класів (рис. 1-а, б).

Значна різниця виявлена у відповідях респондентів щодо можливості реалізації математичної компетентності у фрізичному вихованні школярів. Так, 64,0\% вчителів фрізичної культури та 53,9\% вчителів початкових класів уважають, що математичну компетентність легко реалізувати у фрізичному вихованні. Проте 32,0\% вчителів фрізичної культури та 38,5\% вчителів початкових класів уважають, що математичну компетентність у фрізичному вихованні реалізувати складно (рис. 2).

Результати опитування засвідчили, що існує однакова думка у двох групах респондентів щодо можливості реалізації ключової компетентності «здатність спілкуватися рідною (у разі відмінності від державної) та іноземними мовами» під час уроків фрізичної культури. Не вбачають труднощів у реалізації цієї ключової компетентності 54,0\% вчителів фрізичної культури та $53,9 \%$ вчителів початкових класів. Проте виявлена достовірна різниця між відповідями респондентів у таких моментах: про складність у реалізації висловилися 36\% учителів фрізичної культури та 21,2\% вчителів початкової школи.

Щодо можливості реалізації у фрізичному вихованні школярів такої ключової компетентності, як «громадянські та соціальні компетентності, пов'язані з ідеями демократії, справедливості, рівності, прав людини, добробуту та здорового способу життя, з усвідомленням рівних прав та можливостей», ми отримали таку думку респондентів: 58,0\% учителів фрізичної культури та 50,0\% учителів початкових класів уважають, що реалізувати цю компетентність у фрізичному вихованні школярів легко. Однак 34,0\% вчителів фрізичної культури та 26,9\% вчителів початкових класів уважають, що це складний процес.

На запитання анкети «Чи можливо у фізичному вихованні школярів реалізувати ключову компетентність інноваційність?» 48,0\% учителів фрізичної культури та 42,3\% вчителів початкових класів зазначили, що це зробити досить легко. Подібною виявилися ситуація впровадженням такої ключової компетентності, як «інфрормаційно-комунікативна компетентність». Так, 48,0\% учителів фрізичної культури та 38,5\% вчителів початкових класів переконані, що це зробити у фрізичному вихованні легко.

На запитання анкети «Чи зможете ви реалізувати компетентності в галузі природничих наук, техніці й технологіях у фрізичному вихованні школярів?» 46,0\% учителів фрізичної культури та 42,3\% вчителів початкових класів зазначили, що це зробити легко. Однак для 46,0\% учителів фрізичної культури та 38,5\% вчителів початкових класів це становить труднощі. Дві групи респондентів уважають, що у фрізичному вихованні школярів легко реалізувати також екологічну компетентність. Про це стверджують 62,0\% вчителів фрізичної культури та 61,5\% вчителів початкових класів (табл. 1).

Опитування педагогів показало, що найважче, на думку обох категорій респондентів, виявилося реалізувати таку ключову компетентність у фрізичному вихованні, як «підприємливість та фрінансова грамотність». При цьому вчителям початкових класів це становить значні труднощі. Про легкість реалізації цієї ключової компетентності висловилися 32,0\% вчителів фрізичної культури й лише 13,5\% вчителів початкових класів. Важко реалізувати цю ключову компетентність для 56,0\% учителів фрізичної культури та 57,7\% вчителів початкових класів. Достовірна розбіжність виявлена й у відповідях респондентів щодо неможливої реалізації. Так, 12,0\% учителів фрізичної культури та 28,9\% вчителів початкових класів переконані в неможливості реалізації цієї ключової компетентності у фрізичному вихованні школярів.

Висновки. Отже, думка вчителів фрізичної культури й учителів початкових класів щодо можливостей упровадження ключових компетентностей освітньої реформи «Нова українська школа» у фрізичне виховання школярів є подібною. Для обох категорій респондентів не викликає труднощів реалізувати такі ключові компетентності: вільне володіння державною мовою (98,0\% учителів фрізичної культури та 92,3\% вчителів початкових класів), культурна компетентність (70,0\% учителів фрізичної культури та 69,2\% вчителів початкових класів) і навчання впродовж життя (62,0\% вчителів фрізичної культури та 65,3\% вчителів початкових класів). 


\section{БІБЛІОГРАФІЧНИЙ СПИСОК:}

1. Бібік Н.М. Переваги і ризики запровадження компетентнісного підходу в шкільній освіті. Український педагогічний журнал. 2015. № 1. С. 47-58.

2. Про освіту : Закон України. URL: https://zakon.rada.gov.ua/laws/show/2145-19.

3. Ляшенко О.І. Пріоритети розвитку української школи в умовах ресормування освіти. Збірник наукових праць Кам'янець-Подільського національного університету ім. Івана Огієнка. Серія «Педагогічна». 2016. Вип. 22. С. 39-42.

4. Москаленко Н.В., Сороколіт Н.С., Турчик I.X. Ключові компетентності у фізичному вихованні школярів в рамках реформи «Нова українська школа». Науковий часопис Нац. пед. університету імені М.П. Драгоманова. Серія 15 «Науково-педагогічні проблеми фрізичної культури (фрізична культура $і$ спорт)» : збірник наукових праць. Київ, 2019. C. 223-229.

5. Нова українська школа. Концептуальні засади. URL: https://mon.gov.ua/storage/app/media/ zagalna\%20serednya/nova-ukrainska-shkolacompressed.pdf.

6. Паращенко Л.І. Вдосконалення організації педагогічної діяльності інноваційного навчального закладу за вимогами компетентнісного підходу. URL: http://ps.stateuniversity.ks.ua/file/issue_36/23.pdf.

7. Пометун О.І. Теорія і практика послідовної реалізації компетентнісного підходу в досвіді зарубіжних країн. Компетентнісний підхід у сучасній освіті: світовий досвід та українські перспективи / під заг. ред. О.В. Овчарук. Київ : К.І.С., 2004. С. 16-25.

8. Реформа освіти і науки. Сайт Кабінету Міністрів України. URL: https://www.kmu.gov.ua/diyalnist/ reformi/rozvitok-lyudskogo-kapitalu/reforma-osviti.

9. Рефрормування освіти в Україні: державноуправлінський аспект: навч.-наук. вид. / за заг. ред. Н.Г. Протасової, Н.Г. Протасова, В.І. Лугового, Ю.О. Молчанова та ін. ; Нац. акад. держ. упр. при Президентові України. Київ ; Львів : НАДУ, 2012. 456 c.

10. Савченко О. Упровадження компетентнісного підходу в початкову освіту: здобутки і нерозв'язані проблеми. Рідна школа. 2014. № 4-5. С. 12-16.

11. Секція. НУШ: компетентності для життя в XXI столітті. URL: https://mon.gov.ua/ua/osvita/ zagalna-serednya-osvita/konferenciyi/serpnevakonferenciya-2018/sekciya-nush-kompetentnosti-dlyazhittya-v-21-stolitti.

12. Barnett R. The Limits of Competence: Knowledge, Higher Education and Society. Buckingham: The Society for Research into Higher Education and Open University Press, 1994. 207 p.

13. Raven J., Stephenson J. Competence in the Learning Society. New-York : Peter Lang, 2001. P. 384-437.

14. Westera W. Competences in education: a confusion of tongues. Journal of Curriculum Studies. 2001. № 33 (1). P. 75-88. 